\title{
The impact of signal crayfish (Pacifastacus leniusculus) on the recruitment of salmonid fish in a headwater stream in Yorkshire, England
}

\author{
S. Peay ${ }^{(1)}$, N. Guthrie ${ }^{(2)}$, J. Spees ${ }^{(3)}$, E. Nilsson ${ }^{(4)}$, P. Bradley(5) \\ Received September 19, 2009 / Reçu le 19 septembre 2009 \\ Revised December 19, 2009 / Révisé le 19 décembre 2009 \\ Accepted December 23, 2009 / Accepté le 23 décembre 2009
}

Key-words:

biological

invasion,

crayfish,

impact,

fish

\section{ABSTRACT}

\begin{abstract}
Signal crayfish (Pacifastacus leniusculus) have become increasingly widespread in rivers in Great Britain since their introduction in the late 1970s, causing extensive losses of indigenous white-clawed crayfish and negative impacts on communities of aquatic plants, invertebrates and benthic fish. Angling interests are increasingly concerned about possible impacts of signal crayfish on brown trout, sea trout (Salmo trutta) and Atlantic salmon ( $S$. salar). This study of a limestone headwater stream in the Pennine uplands, Yorkshire, compares density of fish and two species of crayfish in two years. Signal crayfish are progressively replacing white-clawed crayfish. Surveys showed a significant negative relationship between the fish and signal crayfish. Sites with white-clawed crayfish (1-2 crayfish/trap night) had abundant juvenile trout $\left(>47 \cdot 100 \mathrm{~m}^{-2}\right)$. Signal crayfish reached higher abundance (4-8 crayfish/trap night) and those sites had fewer fish $\left(0-18.8 \cdot 100 \mathrm{~m}^{-2}\right)$. The signal crayfish population will expand to other tributaries over time. If similar reduction of salmonid recruitment occurs in those streams, there is potential for significant impacts on an important recreational fishery.
\end{abstract}

\section{RÉSUMÉ}

Impact de l'écrevisse signal (Pacifastacus leniusculus) sur le recrutement en poissons salmonidés dans un ruisseau de tête de bassin dans le Yorkshire, Angleterre

Mots-clés :

invasion

biologique,

écrevisse,

impact,

poissons

\begin{abstract}
L'écrevisse signal (Pacifastacus leniusculus) est de plus en plus répandue dans les rivières de Grande-Bretagne depuis son introduction dans les années 70 , causant d'importantes pertes dans les populations indigènes d'écrevisses à pattes blanches et des impacts négatifs sur les communautés de plantes aquatiques, d'invertébrés et de poissons. Les pêcheurs sont de plus en plus préoccupés par les impacts possibles de l'écrevisse signal sur la truite, la truite de mer (Salmo trutta) et le saumon atlantique (S. salar). Cette étude d'un ruisseau calcaire dans les collines Pennine, Yorkshire, compare les densités de poissons et de deux espèces d'écrevisses durant deux années. L'écrevisse signal a progressivement
\end{abstract}

(1) University of Leeds, Institute of Integrative and Comparative Biology, Leeds, LS2 9JT, UK, stephanie@crayfish.org.uk

(2) Environment Agency, North West Region, UK

(3) Ribble Catchment Conservation Trust, UK

(4) Lund University, Department of Ecology/Limnology, Sweden

(5) University of Sheffield, UK 
remplacé l'écrevisse à pattes blanches. L'étude montre une relation significative négative entre les poissons et l'écrevisse signal. Les sites avec des écrevisses à pattes blanches (1-2 écrevisses par trappe par nuit) ont beaucoup de juvéniles de truite $\left(>47 \cdot 100 \mathrm{~m}^{-2}\right)$. L'écrevisse signal atteint des abondances plus importantes (4-8 écrevisses par trappe par nuit) et ces sites ont moins de poissons $\left(0-18,8 \cdot 100 \mathrm{~m}^{-2}\right)$. La population d'écrevisse signal devrait s'étendre à d'autres cours d'eau. Si une réduction similaire du recrutement en salmonidés se produit aussi dans ces cours d'eau, il y aura probablement un impact significatif sur l'importante pêcherie de loisirs.

\section{INTRODUCTION}

The signal crayfish Pacifastacus leniusculus has been widely introduced in Europe, where it has had significant adverse impacts on European species of crayfish, by competition and by carrying crayfish plague Aphanomyces astaci, which is lethal to the European species (Holdich, 1999). Being large, omnivorous invertebrates, introduced crayfish are capable of changing benthic foodwebs by predation, competition and modification of habitat, including shredding and consumption of macrophytes and by burrowing (Nyström, 1999). Studies have shown that signal crayfish can reduce the abundance of macrophytes (Warner, 1995; Nyström and Strand, 1996; Usio et al., 2009) and similar effects have been found with other crayfish species. A wide range of invertebrates is preyed on by crayfish, with the larger, less mobile invertebrates being significantly reduced, while smaller, fast species are less affected and some species may even benefit from reduced predation by other predatory invertebrates. Adverse impacts of signal crayfish on abundance have been found in snails (Nyström et al., 2001), on chironomids and Trichoptera (Guan and Wiles, 1998), predatory invertebrates and overall invertebrate biomass (Nyström et al., 1996; Stenroth and Nyström, 2003; Crawford et al., 2006).

Interactions between fish and crayfish are more complex. Many fish species include crayfish in their diet (reviewed by Foster and Slater, 1995) and this includes signal crayfish, which are predated on by several fish species, including perch Perca fluviatilis, eel Anguilla anguilla (Blake and Hart, 1995), rainbow trout Oncorhynchus mykiss (Nyström et al., 2001) and brown trout Salmo trutta (Stenroth and Nyström, 2003). Nonetheless, crayfish have avoidance behaviour, such as increased use of shelter, preferential use of shallow water by juveniles and higher activity at night (reviewed by Nyström, 2002). Some species of crayfish, including signal crayfish, use their outstretched chelae to make themselves too large for the gape of fish, although Nyström et al. (2006) showed perch $25 \mathrm{~cm}$ length were able to consume adult crayfish in a lake. Nonetheless, other studies have found that crayfish are able to predate fish eggs (Kempinger, 1988; Savino and Miller, 1991; Dorn and Wodjak, 2004). Competition for shelter has been shown in laboratory conditions between signal crayfish and juvenile Atlantic salmon Salmo salar (Griffiths et al., 2004), with the fish having to spend more time out in open water, where they required greater expenditure of energy to keep their position in the flowing water.

Where more than one fish species is present the interactions may vary, for example, small fish species can be displaced from shelter by crayfish, increasing their vulnerability to predation by piscivorous species (Rahel and Stein, 1988; Light, 2005); or the fish may show reduced growth in the presence of crayfish (Carpenter, 2005). Benthic fish appear to be particularly vulnerable to the effects of predation or competition by crayfish, with reductions in sculpin species in the USA (Light, 2005), and in bullhead Cottus gobio in England (Guan and Wiles, 1997, 1998; Bubb et al., 2009). Whilst Bubb et al. (2009) found some disturbance of bullhead by the indigenous white-clawed crayfish Austropotamobius pallipes, non-indigenous signal crayfish were much more aggressive towards the fish in laboratory trials, causing damage to fins and in some cases, mortality. The same authors found reductions in abundance of bullhead in rivers too when signal crayfish were present. Peay (2002 and unpublished) also regularily found 
bullheads and white-clawed crayfish under the same large cobbles and boulders in several streams in northern England, suggesting that whereas signal crayfish reduce the abundance of bullhead, interactions between the indigenous crayfish and bullhead are minor.

Some studies have not found any evidence of impact of crayfish species on fish. Dietary studies of red swamp crayfish Procambarus clarkii have shown this species is not very efficient at catching live fish (llhéu and Bernardo, 1997) and in a laboratory trial red swamp crayfish did not reduce survival of juveniles of four cyprinid fish species (Xinya, 1995). Stenroth and Nyström (2003) set up enclosures with signal crayfish and brown trout fry (Salmo trutta) in a Swedish stream, but found no effect of crayfish on the survival of the fish. Degerman et al. (2007) reviewed data from electro-fishing surveys in 61 streams in southern Sweden that had a period of two years or more when indigenous noble crayfish Astacus astacus were present and another when crayfish were absent (generally losses due to crayfish plague), but did not find any reduction of abundance of fish related to either signal or noble crayfish in those streams. Where impacts of crayfish on fish do occur, they may be indirect through modification of aquatic food webs. In a long term study of invasion of a lake in Wisconsin USA by rusty crayfish, Orconectes rusticus, Wilson et al. (2004) showed that fish whose diet overlapped with that of the crayfish declined markedly, whereas piscivorous fish did not.

Headwater streams are important spawning grounds for salmonid fish in Britain. Migratory Atlantic salmon and sea trout $S$. trutta return to spawn in their natal rivers and streams after several years at sea and even resident brown trout tend to move upstream into smaller tributaries to find suitable substrates for spawning. If invading signal crayfish have negative impacts on the production of fry or their survival in these streams, this may reduce the population of adult fish over time. It could potentially affect the ability of naturally reproducing populations of brown trout to support recreational angling. This study reports the distribution of an invading population of signal crayfish in a small stream in northern England and presents some evidence for changes in the fish population in the presence of signal crayfish. Possible implications for management of recreational fisheries in rivers are discussed.

\section{STUDY AREA}

\section{$>$ DESCRIPTION}

The study area (Figure 1) is in the upland area of England known as the Yorkshire Dales, an area of low hills and glaciated valleys. Bookill Gill Beck is a small headwater stream approximately $5.1 \mathrm{~km}$ in length, a tributary of Long Preston Beck, in the catchment of the River Ribble. The solid geology is all in the Lower Carboniferous series. At the top of the sub-catchment there is limestone, but where the stream rises, it is overlain by glacial till and peat, at an altitude of approximately $455 \mathrm{~m}$. The geology of the rest of the sub-catchment is primarily sandstone and shales. Bookill Gill Beck is a steep, fast-flowing watercourse. The main study area is a $4.7 \mathrm{~km}$ length of Bookill Gill beck, approximately $0.6 \mathrm{~km}$ from its source down to its confluence with Long Preston Beck. It has a total fall of $133 \mathrm{~m}$, with average gradient of 1:28. The stream is approximately $0.7 \mathrm{~m}$ wide at the top, increasing to an average width of $1.9 \mathrm{~m}$ at the confluence with Long Preston Beck (Figure 2). Long Preston Beck is a larger stream, approximately $4 \mathrm{~m}$ wide upstream of the confluence, approximately $3.8 \mathrm{~km}$ upstream of the River Ribble.

The land use in the sub-catchment is unimproved or semi-improved pasture, grazed by sheep and cattle, with extensive seasonally wet areas dominated by rushes, especially soft rush (Juncus effusus), on the upper slopes and in patches along spring-fed flushes and parts of the valley bottom. A short section of the stream, $120 \mathrm{~m}$, flows through Wildshare Plantation, a conifer woodland, which is the site of introduction of signal crayfish (see section below). There are also some individual broadleaved trees by the streamside in places, mainly in the steepest section, where there are rock outcrops. There are no farmyards, sheep-dips or domestic properties in the catchment of Bookill Gill Beck to affect the good water quality. A road crosses the stream upstream of the study area, but it is a single-track, rural road with little traffic. 


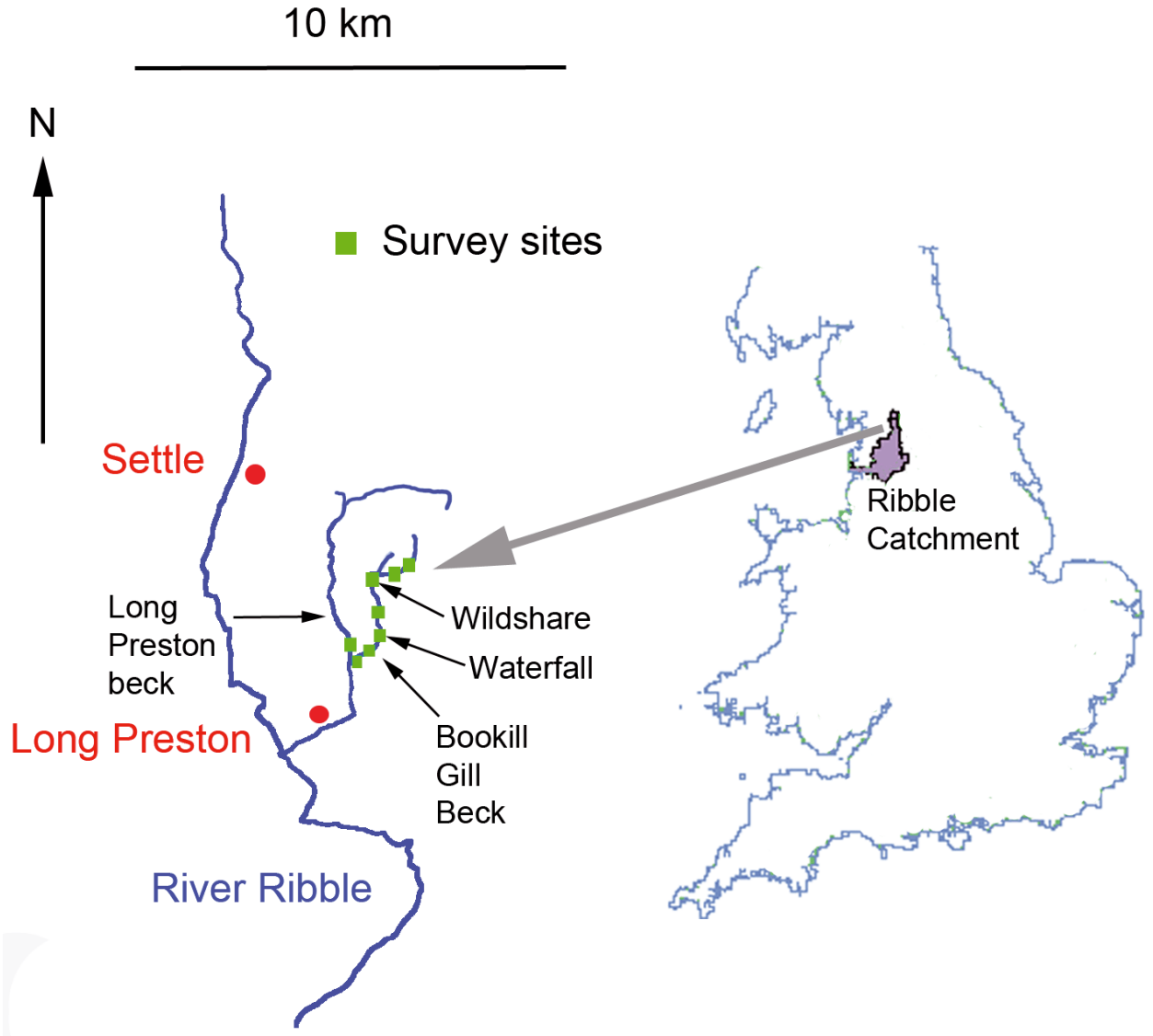

Figure 1

Location of study area showing the Ribble catchment and sites on Bookill Gill Beck.

Figure 1

Localisation de la zone d'étude montrant le basin versant de la rivière Ribble et les sites d'étude sur le Bookill Gill Beck.

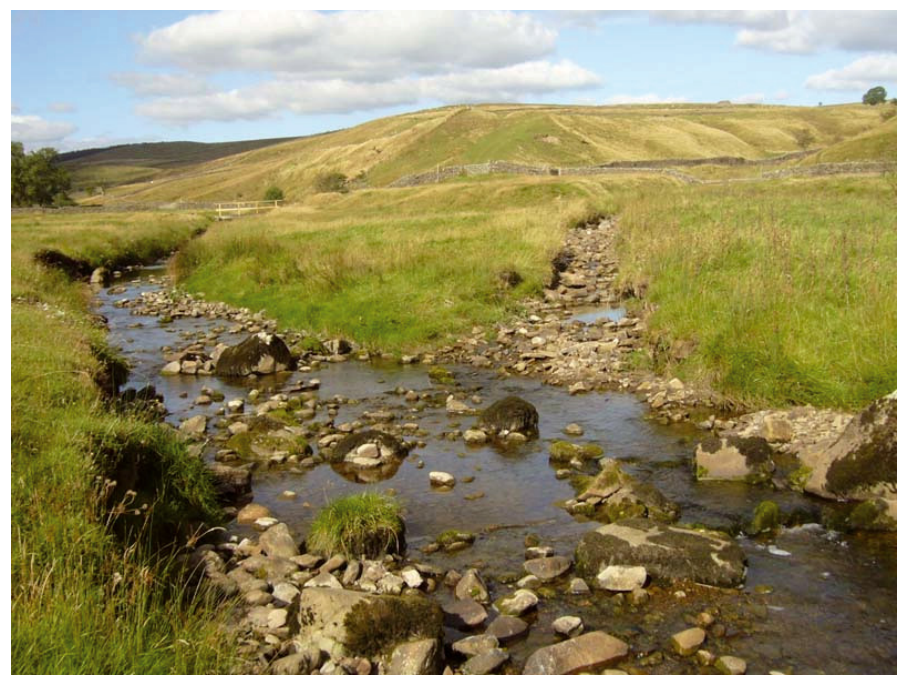

Figure 2

Bookill Gill Beck at the confluence with Long Preston Beck (Bookill Gill Beck on right side).

Bookill Gill Beck à la confluence avec Long Preston Beck (Bookill Gill Beck se trouve sur la droite). 
There is a farm access track running part of the way down the valley of Bookill Gill Beck, but much of the valley is inaccessible, except on foot. There are several small bedrock steps in the middle section of the stream, one of which forms a waterfall. There is little growth of macrophytes in the channel, just occasional patches of aquatic mosses, such as Fontinalis antipyretica and Rhynchostegium riparoides, on some of the more stable boulders and areas of bedrock. Epilithic algae comprise most of the plant growth in the stream.

Rainfall is frequent throughout the year (average monthly rainfall $85 \mathrm{~mm}$ in May to $170 \mathrm{~mm}$ in December), with typically 40-45 days of rainfall in summer (June-August) (Malham Tarn data, MetOffice, 2009). Major spates large enough to move cobbles and boulders occur in the streams every few years, but during periods of low flow the wetted width of the channel decreases and there are frequent short sections of riffle and run where water is less than $100 \mathrm{~mm}$ deep between deeper pools and glides.

\section{> PRESENCE OF CRAYFISH}

Historically, white-clawed crayfish were widely distributed in the catchment of the River Ribble in the main river and the tributaries and in the all the other major catchments of Yorkshire (Don, Calder, Aire, Wharfe, Ure, Swale and Derwent). Now, however, signal crayfish have established at sites in all the catchments (records held by the Environment Agency). Although most populations of signal crayfish in Europe carry crayfish plague, in Yorkshire several populations have established that do not appear to be infected. For example, signal crayfish were stocked into a trout farm at Kilnsey adjacent to the River Wharfe in 1983, from which they have been expanding into a white-clawed crayfish population (Peay and Rogers, 1999; Bubb et al., 2005) and now occupy more than $40 \mathrm{~km}$ of main river (Imhoff, 2009, pers. comm.). A moving zone of mixed population extends over several kilometres of the River Wharfe, yet there have been no outbreaks of crayfish plague recorded there in more than 25 years (to 2008) and no evidence of crayfish plague infection has been found in PCR-tests (Dunn et al., 2009). Similarly, signal crayfish were found in the River Ure in 1997, having escaped from a trout lake and fish farm, and have also expanded into a population of white-clawed crayfish without there being an epidemic of crayfish plague (Bubb et al., 2005).

The River Ribble was affected by crayfish plague in 2001, for which the suspected source was a contaminated consignment of fish stocked into the main river. The spread of the epidemic along the main river and up the tributaries was followed in detail (Bradley, unpublished) while it eliminated all of the white-clawed crayfish in the catchment, except in a few semi-isolated parts, one of which was Bookill Gill Beck. During a survey of the stream in 2002, signal crayfish were found in a mixed population with the white-clawed crayfish (Bradley, unpublished). Local information indicates signal crayfish were stocked into the upper part of the stream at Wildshare Plantation (Figure 1) in about 1995, with reputedly around 4-12 signal crayfish in the original stock (Handy, 2007, pers. comm.). This was an illegal introduction because release of signal crayfish into the wild has been illegal in Great Britain since 1992 (under the Wildlife and Countryside Act 1981 Schedule 9, as amended), except in some areas of southern England.

\section{METHODS}

Fish survey was carried out by electro-fishing, using generator-driven electro-fishing gear, LUG AB, flat DC, $1 \mathrm{~kW}$ in 2007, and a battery-powered electro-fishing gear, Electra Catch International ELBP2, Pulsed DC, $300 \mathrm{~W}$ in 2008, which allowed easier access to sites with no vehicular access. In all the surveys three consecutive runs were carried out (in accordance with a standardised three-run depletion protocol). Fish were identified to species and measured. Substrate, channel characteristics, $\mathrm{pH}$ and conductivity were recorded. Although crayfish were caught and recorded during electro-fishing surveys, this by-catch is not included in the measure of abundance of crayfish, which was done by trapping. One site at the downstream end of Bookill Gill Beck and another on Long Preston Beck were not re-surveyed 
for fish in 2008 , due to disturbance of the channel substrate and fish fry during a separate management operation to remove and re-locate white-clawed crayfish.

Crayfish surveys were carried out using crayfish traps with funnel entrances (LiNi and Trappy Tetra) baited with fish-flavoured cat food. Traps were set for one night and lifted the following morning. Traps were set in the pools and slower-flowing glides, avoiding areas that were too shallow to set the traps, or too fast-flowing for much crayfish activity, based on observations of activity at night (Peay, unpublished). The minimum distance between traps was $3 \mathrm{~m}$ and the maximum approximately $20 \mathrm{~m}$, depending on the habitat present. A total of 15 traps per site was set immediately prior to the electro-fishing surveys in 2007 . There was some variation at sites on Bookill Gill Beck in 2008, where 10-18 traps were used, to utilise sites denoted by the field boundaries. Crayfish surveys were carried out in early September. Trapping was carried out in dry conditions, avoiding rainfall events, which, in this catchment, lead to rapid increases in stream flow and low activity of crayfish. All crayfish caught were recorded for species, sex and size recorded as carapace length $(C L)$ and crayfish abundance at each site was recorded as a Catch Per Unit Effort (CPUE), average number of crayfish per trap. No signal crayfish were returned to the stream (a legal requirement).

Charts were plotted in EXCEL and SPSS. Comparison of fish density and crayfish status was made using non-parametric Kruskall-Wallis tests and between fish density and crayfish abundance using Rank Spearman Correlation tests.

\section{RESULTS}

In 2002 signal crayfish were detected in Bookill Gill Beck, $0.65 \mathrm{~km}$ downstream of the suspected point of introduction approximately seven years previously. By 2008 the detected limits were $3.4 \mathrm{~km}$ downstream and $0.6 \mathrm{~km}$ upstream, using trapping and various intensive manual surveys. This represents a detected rate of expansion of $0.46 \mathrm{~km} \cdot y e \mathrm{er}^{-1}$ downstream and $0.1 \mathrm{~km} \cdot \mathrm{year}^{-1}$ upstream in the period since 2002 , compared to approximately $0.1 \mathrm{~km} \cdot \mathrm{year}^{-1}$ downstream in the initial period of establishment from 1995-2002.

There were no white-clawed crayfish upstream of the signal crayfish population in 2007 and 2008. It is not certain how far upstream they originally occurred beyond the site of introduction of signal crayfish. There is perennial flow upstream of the site of introduction of signal crayfish, although the flow is low in this section in dry years according to local landowners. Whiteclawed crayfish were present downstream of the confluence and in Long Preston Beck in all years, confirmed by surveys since 2002 .

Figure 3 shows the distribution and relative abundance of crayfish (CPUE) recorded in trapping surveys in summer 2007 and 2008 and the total density of fish. At all sites at which signal crayfish were trapped in 2008, the CPUE was higher than in the preceding year (Signed Test, $n=7, P<0.01)$. At the downstream end of Bookill Gill Beck the white-clawed crayfish abundance (CPUE) was typically 2.0 crayfish/trap, but there was a reduction in abundance approximately $1 \mathrm{~km}$ upstream of the confluence with Long Preston Beck, corresponding to an increase in the abundance of signal crayfish. This transition from white-clawed crayfish to signal crayfish is evident in the lower CPUE for white-clawed crayfish at $2.09 \mathrm{~km}$, where CPUE decreased from 0.7 in 2007 to 0.06 in 2008, and at $2.38 \mathrm{~km}$ downstream, where CPUE was 1.5 and 0.7 in 2008 and 2007 respectively. White-clawed crayfish were absent from traps at sites further upstream, although a white-clawed crayfish was recorded a footpath ford (at $1.7 \mathrm{~km}$ ) during a manual survey in 2007 . The signal crayfish population showed much greater abundance than white-clawed crayfish at any site. In habitat formerly occupied by whiteclawed crayfish, CPUE of 7.5 and 8.4 were recorded at Wildshare, the site of the introduction $(0 \mathrm{~km})$ in 2007 and 2008 respectively. The downstream limit of detection of signal crayfish by trapping was at the site $3.1 \mathrm{~km}$ downstream of the introduction, although a few individuals were detected further downstream by intensive manual survey and were confirmed at the confluence by September 2008, approximately $400 \mathrm{~m}$ beyond the limited detected in traps. This equates to a lag in detection of about a year by traps compared to manual survey, based on the rate of expansion calculated above. 


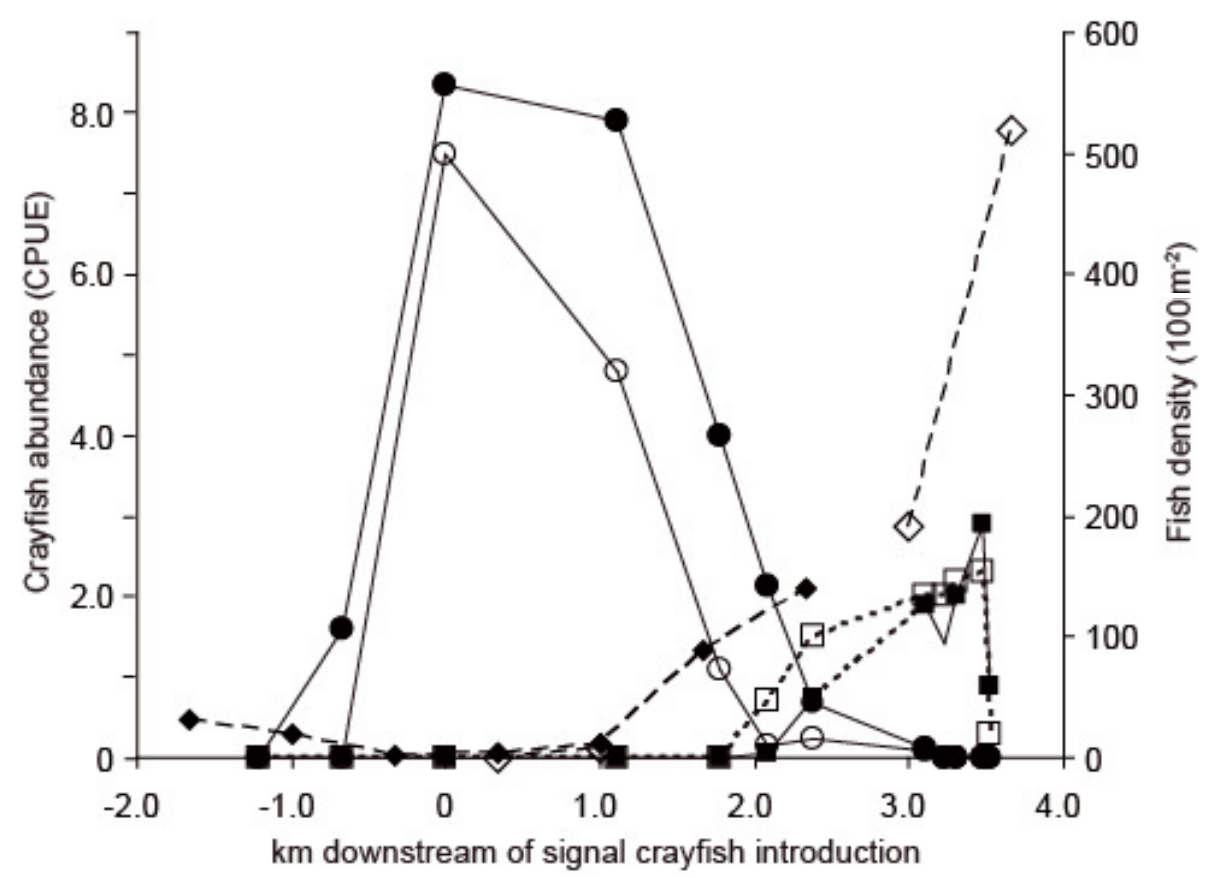

\section{Figure 3}

Abundance of signal crayfish (circle), white-clawed crayfish (square) (CPUE, average number/trap) and density of fish (diamond) (total density. $100 \mathrm{~m}^{-2}$ ) in 2007 (open legend) and 2008 (filled legend). Error bars have been left out for clarity.

\section{Figure 3}

Abondance de l'écrevisse signal (cercle), de l'écrevisse à pattes blanches (carré) (CPUE, nombre moyen par trappe) et densité de poissons (losange) (densité totale.100 m²) en 2007 (losange vide) et 2008 (losange plein).

In addition to higher CPUE being recorded for signal crayfish, individual signal crayfish are able to attain greater size than white-clawed crayfish. This is reflected in the significantly greater cumulative biomass of signal crayfish in traps than white-clawed crayfish (Figure 4) (chi-square $=6.982, \mathrm{df}=2, P<0.03$ ).

The fish population of the stream is principally brown trout Salmo trutta, Atlantic salmon Salmo salar and bullhead Cottus gobio. Eel Anguilla anguilla is also present in low numbers (Figure 5). There are differences in the proportions of substrates at individual sites and within sites (Figure 6), but all are within the range capable of supporting trout in the Ribble catchment. In addition to the substrates in sites in the study area, Figure 6 shows the average composition of substrates at other sites surveyed in the Ribble catchment in 2008 where trout fry densities were high (Class A) or good (Class B) (Class A $>38$ trout fry. $100 \mathrm{~m}^{-2}$, Class B 17-38 trout fry.100 $\mathrm{m}^{-2}$, Mainstone et al., 1994).

The density of fish from electrofishing surveys is shown in Figure 3 in total and is subdivided by fish species in Figure 5 . The most widely distributed species was brown trout, present at all sites, from $-1.2 \mathrm{~km}$ to Long Preston Beck $(3.5 \mathrm{~km})$. The furthest upstream record for trout was at $-1.4 \mathrm{~km}$, a $150 \mathrm{~mm}$ specimen caught as by-catch in a crayfish trap (and so not included in the fish data presented here). Trout were recorded at density in the range 47.5 to $131.9 \cdot 100 \mathrm{~m}^{-2}$ at sites with white-clawed crayfish or mixed crayfish species and at 0 to $18.8 \cdot 100 \mathrm{~m}^{-2}$ at sites with only signal crayfish (Figure 5). Bullhead was only recorded in the electrofishing surveys at the site $2.38 \mathrm{~km}$ from the introduction site and at increasing abundance downstream. Where present bullhead density exceeded the density of trout at the same sites (Figure 5). Juvenile salmon were recorded at the same sites as bullhead in 2008, but were not recorded in 2007. The small waterfall at $1.9 \mathrm{~km}$ downstream of the introduction site is considered to be a barrier to migratory salmonids. Most of the trout recorded in 2008 


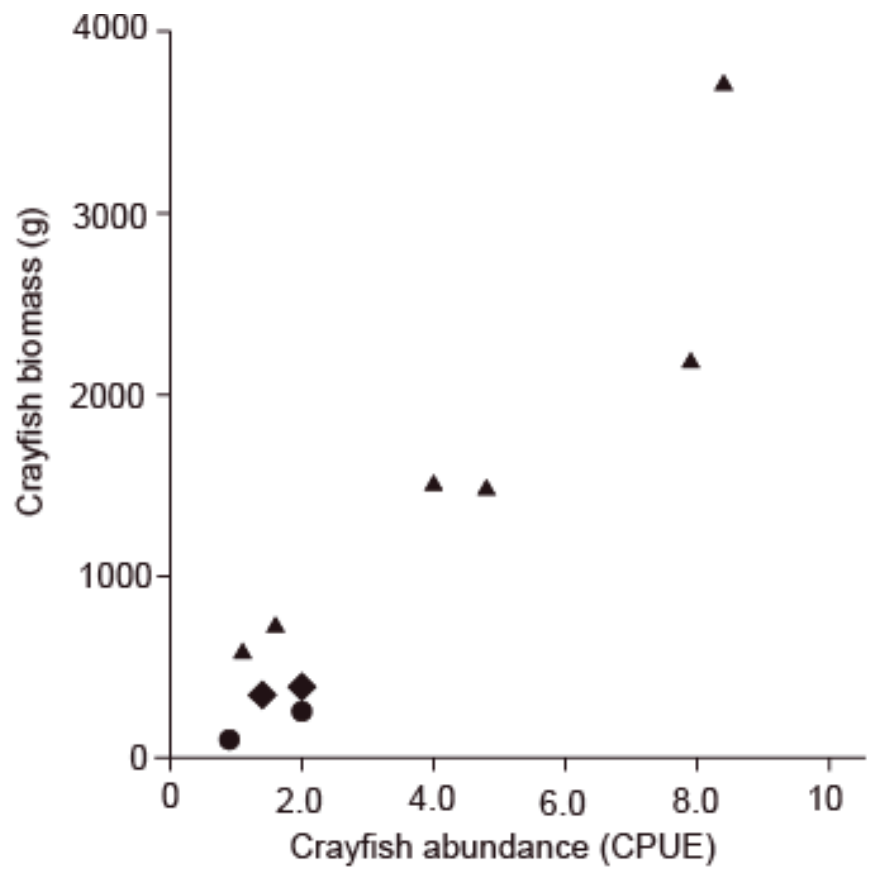

\section{Figure 4}

Biomass of crayfish (per 15 traps) and total abundance as CPUE (average number crayfish/trap) by crayfish status at sites (white-clawed (circle), mixed (diamond), signal crayfish (triangle)).

\section{Figure 4}

Biomasse d'écrevisse (pour 15 trappes) et abondance totale en CPUE (nombre moyen d'écrevisses par trappe) dans les sites (pattes blanches (cercle), mixte (losange), signal (triangle)).

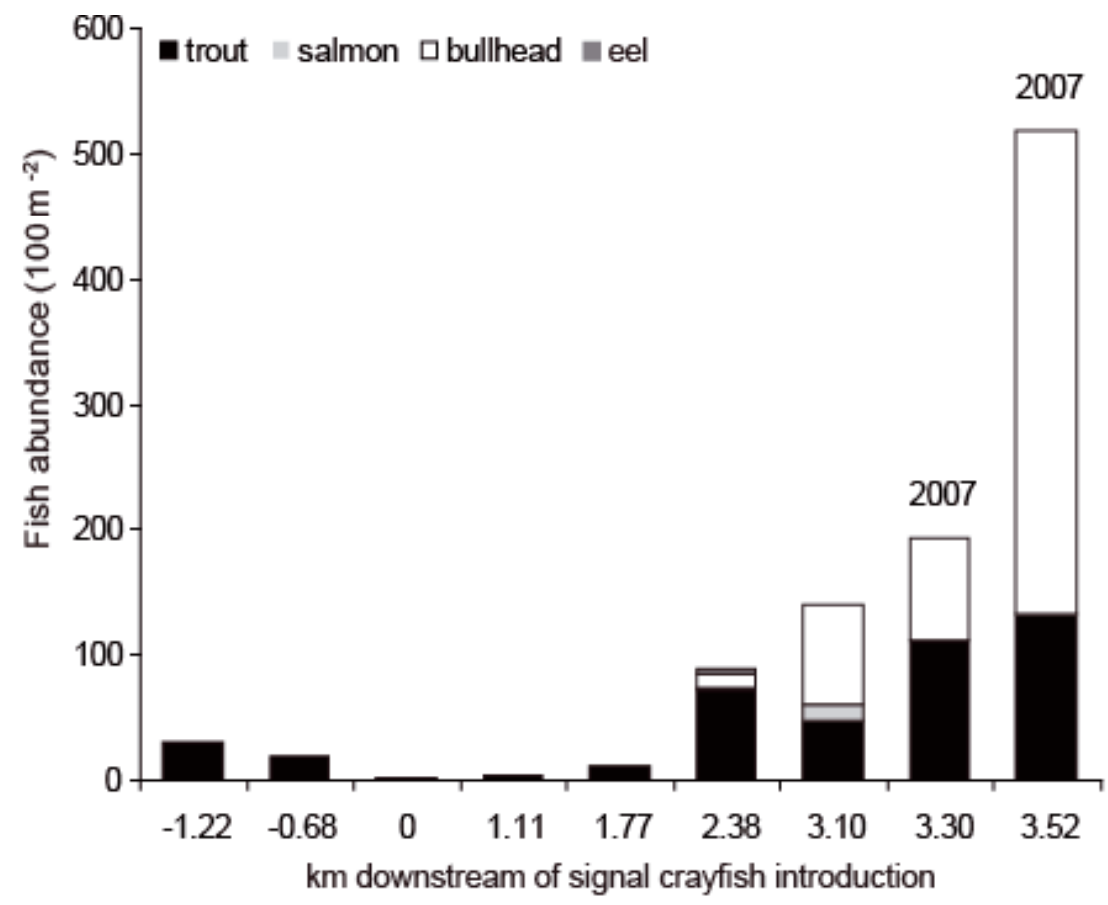

Figure 5

Composition of fish catches by species. 


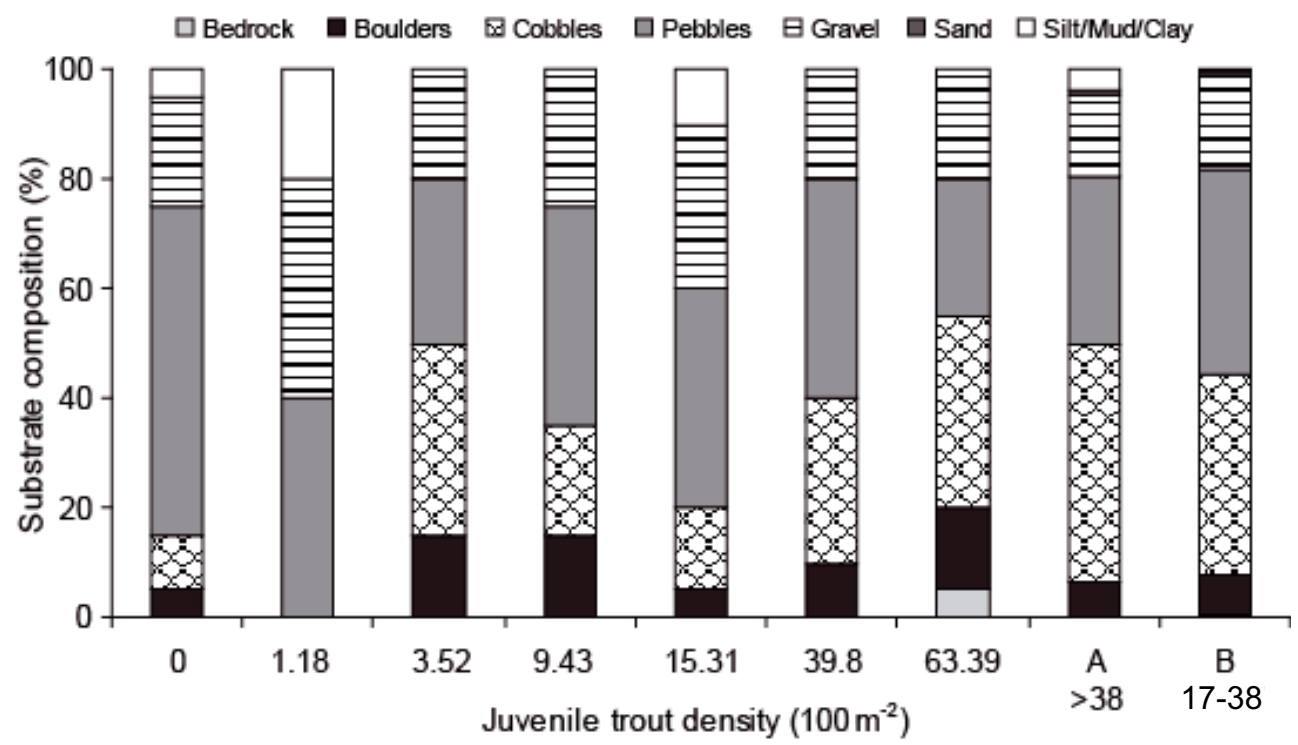

\section{Figure 6}

Substrate composition (\%) at sites in Bookill Gill Beck with the corresponding juvenile trout densities $\left(0-63.39 .100 \mathrm{~m}^{-2}\right)$ and average substrate composition (\%) at sites classified as good habitat (Class $A$, 11 sites and Class B, 19 sites) for juvenile trout in the Ribble catchment in 2008 and the trout densities that are associated with these habitats.

\section{Figure 6}

Composition du substrat (\%) dans les sites de Bookill Gill Beck avec les densités correspondantes de juvéniles de truite $\left(0-63,39 \cdot 100 \mathrm{~m}^{-2}\right)$ et composition moyenne du substrat (\%) dans les sites considérés comme de bons habitats (Classe A, 11 sites et Classe B, 19 sites) pour les juvéniles de truite dans le bassin versant de la rivière Ribble en 2008 et les densités de truites associées à ces habitats.

( $n=165)$ were juveniles, with $83 \%$ of them less than $100 \mathrm{~mm}$ length and only $1.8 \%$ more than $200 \mathrm{~mm}$ in length when recorded during the electro-fishing surveys in early October 2008. There were no trout caught above $250 \mathrm{~mm}$ length.

The by-catch of crayfish during electrofishing is not included in the trapping CPUE or any analysis because the trapping was always carried out in advance, on the previous night in 2007 and variable numbers of days earlier in 2008. Also, the effectiveness of electrofishing for crayfish is reduced where the presence of boulders and abundant refuges in banks make it more difficult to detect crayfish reliably. Nonetheless the by-catch was 0 to 30 crayfish. $100 \mathrm{~m}^{-2}$ at sites with white-clawed crayfish or mixed populations, whereas at two sites with dense signal crayfish in 2008 by-catches were 333 (at $1.1 \mathrm{~km}$ downstream of the introduction site) and 141.1 (at $1.77 \mathrm{~km}$ ).

The density of fish differed at sites according to the status of crayfish at sites (signal crayfish, mixed, white-clawed crayfish or no crayfish), for fish overall (chi-square $=8.045$, df $=3$, $P<0.045$ ) and for trout (chi-square $=8.328, \mathrm{df}=3, P<0.04$ ). There were strong negative correlations between the abundance of signal crayfish and the density of trout (Spearman Rank Correlation $r=-0.881, \mathrm{df}=11, P<0.001)$ and total fish $(r=-0.872, \mathrm{df}=11, P<0.001)$ (Figure 7), but the weak negative correlations for bullhead and salmon respectively were not significant $(r=-0.334$, df $=11, P<0.3 ; r=0.114$, df $=11, P<0.7)$, reflecting the low numbers of sites where salmon and bullhead were recorded.

\section{DISCUSSION}

For the first time, at least in Great Britain, there appears to be field evidence that invading populations of signal crayfish can have a significant effect on the recruitment of brown trout in a headwater stream. Where signal crayfish density is high, the density of juvenile brown 


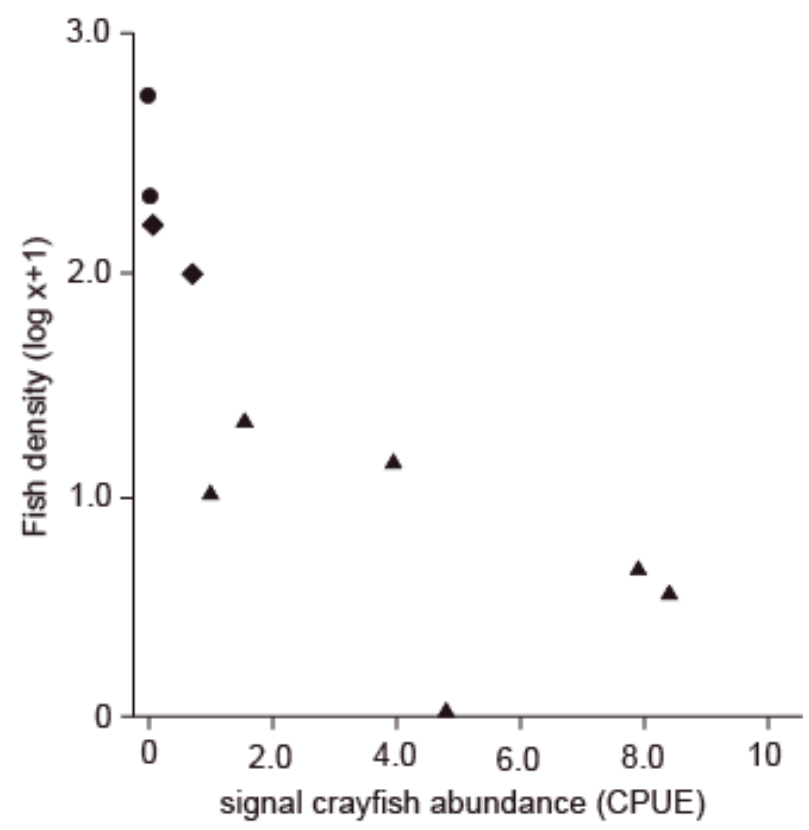

\section{Figure 7}

Correlation between total density of fish $\left(100 \mathrm{~m}^{-2}\right)$ in Bookill Gill Beck and abundance of crayfish (CPUE) (white-clawed (circle), mixed (diamond), signal crayfish (triangle)).

\section{Figure 7}

Corrélation entre la densité totale en poissons $\left(100 \mathrm{~m}^{-2}\right)$ dans Bookill Gill Beck et l'abondance des écrevisses (CPUE) (pattes blanches (cercle), mixte (losange), signal (triangle)).

trout is correspondingly low. In addition bullheads were absent from at least $1.7 \mathrm{~km}$ of stream invaded by signal crayfish where they had previously co-existed with white-clawed crayfish. On its own, a negative correlation between fish and signal crayfish does not indicate whether the signal crayfish are causing reduction of the trout, or some other factor causes trout density to be less in a localised stretch of the stream and this allows signal crayfish to increase due to reduced predation. Furthermore, the sites are not entirely independent of each other and a change in one section of the stream may have indirect effects on other areas.

An important consideration is whether the marked change in the fish populations in Bookill Gill Beck could be accounted for by habitat differences, rather than signal crayfish. The waterfall at $1.9 \mathrm{~km}$ is considered to be a barrier to migratory salmon and sea trout, which explains the lack of salmon upstream of this feature. The lack of access for sea trout upstream could potentially affect the number of adult trout spawning upstream, although even taking this into account the density of trout fry is less than expected in headwater streams in this catchment when there is a resident population of brown trout upstream. The habitat is suitable for trout upstream of the waterfall; the stream is within the normal range of altitude, slope and width of spawning sites for brown trout and the substrate composition is suitable compared to other sites in the Ribble catchment. There are examples of abundant resident populations of brown trout and bullhead upstream of similar or more severe barriers in the Ribble catchment (Spees, unpublished). We also know from local landowners there has been a long-standing population of brown trout upstream of the waterfall. Bullhead and trout were both present upstream of the waterfall at a site $1.1 \mathrm{~km}$ downstream of the introduction in 2002, when there was a mixed population of white-clawed crayfish and signal crayfish (Bradley, unpublished). It appears that bullhead have now been lost completely from the sites upstream of the waterfall, despite there having been no changes in environmental conditions since then that might account for the loss, other than the increase in signal crayfish.

Upstream of the introduction site the increase in density of trout corresponds to a reducing abundance of signal crayfish recorded with distance upstream. In general, the abundance 
of trout would be expected to decrease upstream as the stream became narrower, shallower and steeper upstream (in this case there are also frequent small steps and shallow gravel runs in the uppermost site), but the data shown in Figures 3 and 5 do not follow the expected trend and trout are still present and at higher abundance than in the stretch with signal crayfish. The results from the transition zone at the downstream end of the invaded stretch are also indicative. Downstream of the small waterfall, there is a stretch that extends to the confluence with Long Preston Beck with no major barriers to salmonids and where trout density is high. The presence of abundant trout (and other fish species) does not appear to have been able to suppress the increase in abundance of signal crayfish from 2007 to 2008 in the transition zone with white-clawed crayfish, or elsewhere. Hence the reduction in fish recorded in Bookill Gill Beck is most probably due to the high abundance and high biomass of signal crayfish.

Degerman et al. (2007) found no effect of signal crayfish on juvenile trout, even at high density of crayfish (25-100 crayfish.100 $\mathrm{m}^{-2}$ ) in electro-fishing catches. Electrofishing catches of crayfish are not directly comparable with trapping CPUE, but the sites in Bookill Gill Beck with the highest trapping CPUE also had the highest by-catches of crayfish in electrofishing, and these were greater than the highest densities recorded by Degerman et al. (2007). In another study of Swedish streams, Nilsson et al. (2008) had trapping CPUE for signal crayfish at less than 1.0 in 8 out of 10 streams, which is less than the CPUE recorded here, even for whiteclawed crayfish. It is not clear why signal crayfish are able to achieve such high abundance in this stream compared to Swedish streams.

In future years, we expect to see increases in abundance in signal crayfish in the lower part of Bookill Gill Beck and Long Preston Beck and we forecast a reduction in the fish population, compared to sites with white-clawed crayfish only, or no crayfish. Signal crayfish in invading populations in England expand their range progressively, although the rate varies, generally slow during establishment and more rapidly thereafter, with typical rates of around 1-2 km.year ${ }^{-1}$ in both lowland rivers (Guan and Wiles, 1996) and in the upland rivers of Yorkshire (Peay and Rogers, 1999; Bubb et al., 2005). The current rate of expansion in Bookill Gill Beck is slower (less than $0.5 \mathrm{~km} \cdot \mathrm{year}^{-1}$ ), but now that the population has reached high abundance in part of its range and has overcome any delaying factor of the small waterfall, it is possible that the rate of expansion may accelerate in the next few years.

The data presented here do not show the mechanism of loss of recruitment in Bookill Gill Beck and it is possible than several factors are in operating in combination. At least some predation of fish by crayfish occurs. We observed many trout in the zone with signal crayfish with fin damage, or with bruising which was unlikely to be attributable to damage during electrofishing. We also caught a dying trout (95 mm length) with a cut in its throat unmistakeably made by the chela of a crayfish but with no other visible indications of damage or poor condition. By contrast, Stenroth and Nyström (2003) caged batches of 20 trout fry (average $31.6 \mathrm{~mm}$ length) with either 5 or 10 signal crayfish of three size classes $(15,23$ and $45 \mathrm{~mm}$ carapace length (CL)) in a Swedish stream, but did not find any evidence of injuries and no differences in trout survival, length or weight, despite the fish being smaller sizes than those caught at the end of summer in Bookill Gill Beck. Predation of large trout fry and parr by signal crayfish in Bookill Gill Beck may simply be opportunistic, when the fish pass within reach of the crayfish. The opportunities for predation by crayfish may be higher in this stream due to the locally shallow water during periods of low flow, which increases the chance of fish being within grasping range of crayfish, or may be a minor effect compared to other sources of impact.

Shelters that are resistant to high flows are likely to be important to both fish and crayfish in this steep, spate stream. Signal crayfish utilise the refuges under stones in the channel and also make use of undercut banks and burrows that cannot be used by the fish. In the areas with the highest trapping CPUE, signal crayfish appear to occupy almost all the potentially usable refuges in the channel when a manual search is carried out. Griffiths et al. (2004) showed salmon fry had to spend more time swimming in open water when signal crayfish occupied refuges. Reduced access to refuges may make the juvenile fish more vulnerable to 
being washed away during floods. Floods appears to be an important factor in recruitment of salmonids from year to year, with Ribble Catchment Conservation Trust reporting reduced abundance of juvenile trout in late summer surveys if there have been large or more frequent flood events in the preceding winter and spring. Avoiding the crayfish in refuges may also leave the fish potentially vulnerable to increased predation, especially by grey herons Ardea cinerea, which regularly hunt along the stream and have a roost site nearby. Another possibility is that signal crayfish are helping to displace fish downstream and that due to the relatively steep gradient and at least one barrier, fewer fish are able to migrate back to take residence or spawn.

We have no information at present on the degree to which signal crayfish in this stream predate fish eggs or emerging fry. Signal crayfish are assumed to be relatively inactive in streams during the winter. Spawning of brown trout occurs in streams in the Ribble catchment in the period late October to December, depending on flows. The late spawning period may reduce the opportunity for predation of eggs by crayfish, but with such high density of signal crayfish there may be pressure to forage even in winter, when there are readily accessible and nutritious fish eggs and larvae. This is particularly so as there has been a pattern of mild winters in northern England in recent years, with only a few days of snow each winter at most. The trout alevins emerge from the gravel in March and April. Depending on the water temperature during incubation, active swimming and avoidance of predators would not be expected until late May or early June. With crayfish in Yorkshire showing increasing activity in April and May, there is the potential for predation when small juvenile trout are at their most vulnerable.

In addition, observations on site suggest there are changes in the composition of the inverterbrate fauna in the signal crayfish zone, such as reduction or loss of Gammarus pulex, an important food source for trout. This has not been investigated in any detail as yet, but the findings of reduced invertebrate biomass (Stenroth and Nyström, 2003; Crawford et al., 2006) suggest this is another possible pathway for impact of signal crayfish on fish.

This is a case study of a single stream and as such we cannot assume that the effects would be seen in other invaded streams. It may be that there are characteristics of this stream that have allowed it to develop an especially high abundance of signal crayfish. Certainly, the stream is shallow and the density of adult trout is low - the stream is primarily a recruitment area and it is not stocked with reared fish. In addition, in this case, the signal crayfish were introduced near the upstream end of a small tributary, whereas it is more common for introductions of signal crayfish to be made in less remote areas in the larger streams or main rivers, from which they expand slowly up in to the tributaries. Nonetheless there are many similar shallow, stony headwater streams in this catchment and in many other catchments in upland areas of northern England and Scotland, and these are important for recruitment of salmonids. An increasing number of those catchments have signal crayfish populations expanding in one or more areas.

Since the outbreak of crayfish plague in the River Ribble, the Manchester Anglers Association has changed its management of the fishery from extensive annual stocking of trout to a largely wild fishery. The Ribble Catchment Conservation Trust, which advises angling interests in the catchment, recommends stocking only in compensation for damaging events, such as temporary loss of spawning habitat due to modifications of the river. The Trust and local landowners have invested in a range of habitat improvement measures, including fencing of some stretches to protect river banks from excessive erosion by livestock, dealing with incidents of farm pollution and generally trying to improve the natural production of brown trout and Atlantic salmon in the catchment. The possibility that similar impacts on recruitment of salmonids may be seen in other tributaries over time is a matter of concern to the Ribble Catchment Conservation Trust.

Guan and Wiles (1997) have shown that an invading population of signal crayfish can have an impact on benthic fish; bullhead and stone loach Barbatula barbatula. These species are important elements of the overall aquatic biodiversity, but are not of interest for angling. Although the negative impact of signal crayfish on white-clawed crayfish is widely known, there 
appears to have been little published on the impact of signal crayfish on angling, apart from the nuisance of crayfish taking angling bait in some cyprinid fisheries (Peay and Hiley, 2004). Anglers on the River Wharfe have reported catching brown trout which have eaten juvenile crayfish (Birdsall, 2007, pers. comm.) and this has led some of them to assume that signal crayfish solely provide benefits to the recreational fishery.

If impacts that appear to be occurring in Bookill Gill Beck do indeed occur in at least some other watercourses, there is potential for adverse impacts on recreational fisheries which are dependent on recruitment of fish from small headwater streams. Non-indigenous crayfish would be just one of the factors with potential for effects on recruitment, however. Other factors such as land use, water quality, the presence of artificial barriers, the frequency of flood and drought events and fish harvesting regimes may be equally or more important - it is too early to tell, but additional negative impacts from signal crayfish may exacerbate other adverse factors.

Fisheries management policy in Great Britain is increasing encouraging management of natural salmonid fisheries, rather than stocking, so we believe that the potential for invasive non-indigenous crayfish to adversely affect recruitment of fish, including salmonid fish, is a matter that should be investigated further. We hope that this case study will encourage other studies on this topic. Above all, as a precautionary measure to protect both fish and other elements of biodiversity, we hope that those involved in using, managing or regulating recreational fisheries will increase their efforts to prevent further introductions of non-indigenous crayfish in Great Britain and elsewhere.

\section{ACKNOWLEDGEMENTS}

The work on Bookill Gill Beck was funded by the Environment Agency, Northwest Region, with additional support from the Esme Fairburn Foundation and Tubney Trust, also Yorkshire Dales National Park and Ribble Catchment Conservation Trust. E.N. was funded by the Crafoord Foundation and the Lars Hierta Memorial Foundation. Thanks go to Patrik Stenroth and Steve Hatton for help on the fisheries surveys; Hilary Gould, Alex Caveen and several other volunteers who helped with the various crayfish surveys in Ribbledale in 2007 and 2008; all the landowners who allowed the surveys to be carried out; Bill Kunin, University of Leeds for advice on analysis; Paul Bryden for assistance with graphics, and Colin Bean of Scottish Natural Heritage and Patrik Stenroth for helpful advice on an early draft of this paper.

\section{REFERENCES}

Birdsall J., 2007. Grassington Angling Association, Grassington, North Yorkshire, UK, Personal communication.

Blake M.A. and Hart P.J.B., 1995. The vulnerability of juvenile signal crayfish to perch and eel predation. Freshw. Biol., 33, 233-244.

Bubb D.H., Thom T.J. and Lucas M.C., 2005. The within-catchment invasion of the non-indigenous signal crayfish (Dana) in upland rivers. Bull. Fr. Pêche Piscic., 376-377, 665-673.

Bubb D.H., O’Malley O.J., Gooderham A.C. and Lucas M.C., 2009. Relative impacts of native and nonnative crayfish on shelter use by an indigenous benthic fish. Aquat. Conserv., 19, 448-455.

Carpenter J., 2005. Competition for food between an introduced crayfish and two fishes endemic to the Colorado River basin. Environ. Biol. Fishes, 72, 335-342.

Crawford L., Yeomans W.E. and Adams C.E., 2006. The impact of the introduced signal crayfish Pacifastacus leniusculus on stream invertebrate communities. Aquat. Conserv., 16, 611-621.

Degerman E., Nilsson P.A., Nyström P., Nilsson E. and Olsson K., 2007. Are fish populations in temperate streams affected by crayfish? - A field survey and prospects. Environ. Biol. Fishes, 78, 231-239.

Dorn N.J. and Wojdak J.M., 2004. The role of omnivorous crayfish in littoral communities. Oecologia, 140, 150-159. 
Dunn J.C., McClymont H.E., Christmas M. and Dunn A.C., 2009. Competition and parasitism in the native white clawed crayfish Austropotamobius pallipes and the invasive signal crayfish Pacifastacus leniusculus in the UK. Biol. Invasions, 11, 315-324.

Foster J. and Slater F.M., 1995. A global review of crayfish predation with observations on the possible loss of Austropotamobius pallipes in the Welsh Wye due to crayfish plague. Freshwater Crayfish, 8, 589-613.

Griffiths S.W., Collen P. and Armstrong J.D., 2004. Competition for shelter among overwintering signal crayfish and juvenile Atlantic salmon. J. Fish Biol., 63, 436-447.

Guan R.-Z. and Wiles P.R., 1996. Growth, density and biomass of crayfish, Pacifastacus leniusculus, in a British lowland river. Aquat. Living Resour., 9, 265-272.

Guan R.Z. and Wiles P.R., 1997. Ecological impact of the introduced crayfish Pacifastacus leniusculus on benthic fish in a British lowland river. Conserv. Biol., 11, 641-647.

Guan R.-Z. and Wiles P.R., 1998. Feeding ecology of the signal crayfish Pacifastacus leniusculus in a British lowland river. Aquaculture, 169, 177-193.

Handy N., 2007. Environment Agency, North West Region, Preston, Lancashire, UK, Personal communication.

Holdich D.M., 1999. The negative effects of established crayfish introductions. In: Gherardi F. and Holdich D.M. (eds.), Crayfish in Europe as Alien Species: How to make the best of a bad situation, A.A. Balkema, Rotterdam, 31-46.

Ilhéu M. and Bernardo M., 1997. Experimental evalution of food preferences of red swamp crayfish Procambarus clarki: vegetal versus animal. Freshwater Crayfish, 9, 359-364.

Imhoff E., 2009. Institute of Integrative and Comparative Biology, University of Leeds, Leeds, UK, Personal communication.

Kempinger J.J., 1988. Spawning and early life history of lake sturgeon in the Lake Winnebago system, Wisconsin. Am. Fish. Soc. Symp., 5, 110-122.

Light T., 2005. Behavioural effects of invaders: alien crayfish and native sculpin in a California stream. Biol. Invasions, 7, 353-367.

Mainstone C.P., Barnard S. and Wyatt R.J., 1994. Development of a Fisheries Classification Scheme, R\&D Project Record 244/7/NY, National Rivers Authority, Bristol.

MetOffice, 2009. http://www.metoffice.gov.uk/climate/uk/nw/.

Nilsson E., Persson A., Nyström P., Stenroth P. and Olsson K., 2008. Species densities, spatial complexity and resource diversity affects niche width and niche overlap among stream-dwelling consumers. In: Nilsson E. (ed.), Species interactions in streams - effects of predation, competition and ecosystem properties, Ph.D. Dissertation, Lund University, 45-58.

Nyström P., 1999. Ecological impact of introduced and native crayfish on freshwater communities: European perspectives. In: Gherardi F. and Holdich D.M. (eds.), Crayfish in Europe as Alien Species: how to make the best of a bad situation, A.A. Balkema, Rotterdam, 63-85.

Nyström P., 2002. Ecology. In: Holdich D.M. (ed.), Biology of Freshwater Crayfish, Blackwell Science, Oxford, 192-235.

Nyström P. and Strand J.A., 1996. Grazing by a native and an exotic crayfish on aquatic macrophytes. Freshw. Biol., 36, 673-682.

Nyström P., Brönmark C. and Granéli W., 1996. Patterns in benthic food webs: a role for omnivorous crayfish? Freshw. Biol., 36, 631-646.

Nyström P., Svensson O., Lardner B., Brönmark C. and Granelí W., 2001. The influence of multiple introduced predators on a littoral pond community. Ecology, 82, 1023-1039.

Nyström P., Stenroth P., Holmqvist N., Berlund O., Larsson P. and Granelí W., 2006. Crayfish in lakes and streams: individual and population responses to predation, productivity and substratum availability. Freshw. Biol., 51, 2096-2213.

Peay S., 2002. Monitoring Protocol for White-clawed Crayfish Field-testing in the River Eden Tributaries, Summer 2002 Life in UK Rivers Contract No. LIF 02-11-37 Conserving Nature 2000 Rivers, English Nature, Peterborough, 57 p., http://www.english-nature.org.uk/LIFEinUKRivers/species/crayfish. html.

Peay S. and Hiley P.D., 2004. A Review of Crayfish and Angling, Unpublished report, Environment Agency, Thames Region, Hatfield. 
Peay S. and Rogers D.R., 1999. The peristaltic spread of signal crayfish (Pacifastacus leniusculus) in the River Wharfe, Yorkshire, England. Freshwater Crayfish, 12, 665-676.

Rahel F.J. and Stein R.A., 1988. Complex predator-prey interactions and predator intimidation among crayfish, piscivorous fish, and small benthic fish. Oecologia, 75, 94-98.

Savino J.F. and Miller J.E., 1991. Crayfish (Orconectes virilis) feeding on young lake trout (Salvelinus namaycush): effect of rock size. J. Freshwater Ecol., 6, 161-170.

Stenroth P. and Nyström P., 2003. Exotic crayfish in a brown water stream: effects on juvenile trout, invertebrates and algae. Freshw. Biol., 48, 466-475.

Usio N., Kamiyama R., Saji A. and Takamua N., 2009. Size-dependent impacts of invasive alien crayfish on a littoral marsh community. Biol. Conserv., 142, 7, 1480-1490.

Warner G.F., 1995. Choice and consumption of aquatic weeds by signal crayfish (Pacifastacus leniusculus). Freshwater Crayfish, 8, 360-363.

Wilson K.A., Magnuson J., Lodge D.M., Hill A.M., Kratz T.K., Perry W.L. and Willis T.V., 2004. A long-term rusty crayfish (Orconectes rusticus) invasion: dispersal patterns and community change in a north temperate lake. Can. J. Fish. Aquat. Sci., 61, 2255-2266.

Xinya S., 1995. Effect of the crayfish Procambarus clarkii on the survival of the fry and fingerlings of fishes cultivated in China. Freshwater Crayfish, 8, 528-532. 